CESIS Electronic Working Paper Series

Paper No. 192

\title{
Equity Financing and Innovation: Is Europe Different from the United States?
}

\author{
Gustav Martinsson \\ (CESIS and the Division of Economics, KTH)
}

August 2009

The Royal Institute of technology

Centre of Excellence for Science and Innovation Studies (CESIS) 


\title{
Equity Financing and Innovation:
}

\section{Is Europe Different from the United States?}

\begin{abstract}
During the mid and late 1990s young, high-tech firms in the U.S. experienced a supply shift in both internal and external equity fueling a finance driven boom in corporate R\&D. I estimate dynamic R\&D regression models for high-tech firms, separately for the U.K. and Continental Europe, and find significant cash flow effects for newly listed firms in both samples, but only the new, high-tech firms in the U.K. experienced a supply shift in external equity as well. The findings of this paper suggest a channel through which market based financial systems outperform the bank based economies of Continental Europe.
\end{abstract}

Keywords: Financing constraints; R\&D; Stock Issues; Econometrics; Financial markets; international economics

JEL: G32; O32 


\section{Introduction}

Recent evidence suggests that the U.S. experienced a finance driven R\&D boom in the late 1990s (Brown, Fazzari and Petersen, 2009 - BFP (2009) hereon). Young, high-tech firms benefited from supply shifts in both internal and external equity which relaxed otherwise binding financing constraints for R\&D investment. The findings in BFP (2009) suggest that there exists a significant connection between finance, innovation, and growth. In this paper I examine whether R\&D spending in Europe was similarly sensitive to fluctuations in the availability of internal and external equity finance during the late 1990s and early 2000s. I focus on R\&D investment in the U.K. and nine other developed European economies (Continental Europe). The U.K. is particularly interesting to study because it is most like the U.S. in having a market based financial system experiencing a sharp stock issue boom in the late 1990s.

The results are obtained from analyzing 700 publicly traded, high-tech firms incorporated in Belgium, Denmark, Finland, France, Germany, the Netherlands, Norway, Sweden, Switzerland, and the U.K. during the period from 1995 to 2004. Roughly 40 percent of the firms are incorporated in the U.K. I estimate dynamic Euler equation models with generalized methods of moments (GMM) estimation separately for U.K., and Continental European, hightech firms. The joint equity estimates for new, U.K., high-tech firms are quantitatively large and statistically significant. The regression for new, Continental European, high-tech firms only provides a significant joint cash flow effect. The results are robust to considering alternative sample splits, estimation procedures, and instrument lag lengths.

New, Continental European, high-tech firms also experienced a stock issue boom in the late 1990s, but this did not matter for R\&D as it did for new, U.K. high-tech firms. Also, R\&D normalized by total assets and net stock issuance normalized by total assets were higher 
for, new, U.K., high-tech firms than for new, Continental European, high-tech firms. In the boom year of 1999, new, U.K., high-tech firms had an average R\&D intensity of 0.207 compared to 0.155 for new, Continental European, high-tech firms. The major difference lies in the net stock issuance variable where new, U.K., firms had an average of 0.333 during the sample period compared to 0.220 for new, Continental European, high-tech firms. The empirical analysis suggests that the reason for the higher R\&D intensity of new, U.K., hightech firms compared to that of high-tech firms from Continental Europe is their access to external equity which they spent on additional R\&D investment.

My findings on European, high-tech firms corroborate BFP's (2009) U.S. findings and contain important implications. U.S. and U.K., high-tech firms appear to have similar R\&D intensities and uses of cash flow and also seem to depend on net stock issuance to a similar degree. Thus, it appears as if market based financial systems are better at providing external finance to R\&D investing firms at lower costs. The literature agrees that because of capital market imperfections, firms without adequate internal finance may face binding financing constraints for R\&D investment (Carpenter and Petersen, 2002; Hall, 2002). This could be a channel through which the nature of a country's financial system influences its economic growth. Beck and Levine (2002) cannot find evidence of either market or bank based financial systems facilitating economic growth better. The U.S. and U.K. with their market-based financial systems appear to support R\&D intensive firms better than bank-based Continental European economies. Combining these findings with the importance assigned to $R \& D$ in endogenous growth models (Aghion and Howitt, 1992; 1998) this is a potential channel through which market-based financial systems outperform the bank-based economies of Continental Europe.

The paper proceeds as follows. Section 2 presents the empirical strategy. Section 3 includes the presentation of the data alongside the descriptive statistics and graphical 
evidence. Section 4 presents the dynamic GMM results and tests their robustness. Section 5 summarizes and discusses the implications of the findings.

\section{Econometrics and estimation}

R\&D investment specifications used in the empirical literature are almost exclusively transformations of capital investment specifications. To my knowledge, BFP (2009) are the first to apply an Euler equation model, derived in Bond and Meghir (1994) for capital investment, to R\&D investment. I apply the same specification.

The Bond and Meghir (1994) model relates capital investment rates between successive periods and is derived from dynamic optimization with symmetric and quadratic adjustment costs. Herein lies the advantage of the Euler equation; assuming expectations are formed according to the previously mentioned dynamic optimization scenario, the Euler equation specification controls for expectational influences affecting the investment decision. Since expectational influences are controlled for it is more straightforward and less ambiguous to interpret the estimation results and to draw conclusions from the econometric estimates.

Equations (1) and (2) below are the same as in BFP (2009, p. 162). When equation (1) holds, the impact of expectations on investment is controlled for and based on the sign in front of $\beta_{3}$ the sample-firm is considered not to be financially constrained. Moreover, besides the sign in front of $\beta_{3}, \beta_{1}$ should be slightly larger than one, and $\beta_{2}$ negative and slightly less than one. The sample of firms satisfying these estimation restrictions are considered not to be financially constrained. Thus, meeting these target values implies not rejecting $H_{0}$, and subsequently the baseline Euler equation model of Bond and Meghir (1994) holds. 


$$
\begin{aligned}
& \left(\frac{R D_{i, t+1}}{T A_{i, t}}\right)=\beta_{0}+\beta_{1}\left(\frac{R D_{i, t}}{T A_{i, t-1}}\right)-\beta_{2}\left(\frac{R D_{i, t}}{T A_{i, t-1}}\right)^{2}-\beta_{3}\left(\frac{\mathrm{CF}_{i, t}}{T A_{i, t-1}}\right) \\
& +\beta_{4}\left(\frac{\mathrm{Y}_{i, t}}{T A_{i, t-1}}\right)+\alpha_{t+1}+\alpha_{i}+\varepsilon_{i, t+1}
\end{aligned}
$$

Equation (2) follows BFP (2009) with the purpose of exploring corporate financing constraints. In practice this implies testing the impact of internal and public equity as financing sources of R\&D investment. The added variables are: contemporaneous cash-flow, since it is the standard measure in the literature for internal financing of investment; contemporaneous output since the high correlation between sales and cash-flow otherwise may inflate the cash-flow estimate; and contemporaneous and lagged net stock issuance (abbreviated $s t k_{i, t+1}$ and $\mathrm{stk}_{i, t}$ respectively in equation (2)). A sample satisfying specification (2) rejects the proposed null hypothesis of no financing constraints.

$H_{1}:$ The baseline Euler equation needs to be augmented with financial variables,

\section{i.e. financing constraints}

$$
\begin{aligned}
& \left(\frac{R D_{i, t+1}}{T A_{i, t}}\right)=\beta_{0}+\beta_{1}\left(\frac{R D_{i, t}}{T A_{i, t-1}}\right)-\beta_{2}\left(\frac{R D_{i, t}}{T A_{i, t-1}}\right)^{2}+\beta_{3}\left(\frac{\mathrm{CF}_{i, t+1}}{T A_{i, t}}\right) \\
& -\beta_{4}\left(\frac{\mathrm{CF}_{i, t}}{T A_{i, t-1}}\right)+\beta_{5}\left(\frac{\mathrm{Y}_{i, t+1}}{T A_{i, t}}\right)+\beta_{6}\left(\frac{\mathrm{Y}_{i, t}}{T A_{i, t-1}}\right)+\beta_{7}\left(\frac{\mathrm{stk}_{i, t+1}}{T A_{i, t}}\right)+\beta_{8}\left(\frac{\mathrm{stk}_{i, t}}{T A_{i, t-1}}\right) \\
& +\alpha_{t+1}+\alpha_{i}+\varepsilon_{i, t+1}
\end{aligned}
$$


The adjustment costs associated with $R \& D$ investment are supposedly higher than for other types of investment. The literature highlights two reasons for why this might be so. The lion's share of corporate R\&D expenditure comprises salary to researchers and firms are normally reluctant to fire researchers since they have invested a lot of time and funds for training them. Firing $R \& D$ workers is also problematic due to the disclosure issues of $R \& D$ projects. Therefore firms choose to smooth their R\&D expenditure to minimize the risk of having to drastically cut in the R\&D budget. This topic is thoroughly discussed in Hall (2002) and Himmelberg and Petersen (1994).

The higher adjustment costs associated with R\&D, and the subsequent smoothing of corporate $R \& D$ expenditure, result to the $R \& D$ time series being highly persistent. This is why modeling R\&D investment requires a dynamic specification. Ordinary least squares (OLS) and within estimation are recognized as biased estimators of short dynamic panel data sets. ${ }^{1}$ I therefore estimate equations (1) and (2) using general methods of moments (GMM) estimation.

\section{Data description and sample characteristics}

\subsection{Sample construction}

This paper follows the sample selection of BFP (2009) as closely as possible in order to obtain comparable results. BFP (2009) restrict their analysis to high-tech firms. They base their definition of high technology sectors on a report by the United States Commerce

\footnotetext{
${ }^{1}$ See Bond (2002) and Roodman $(2006,2008)$ for descriptions of the estimation of dynamic panel data sets regarding OLS, within, and GMM estimation.
} 
Department on U.S. competitiveness in high technology. ${ }^{2}$ Aerospace manufacturing is excluded from the high-tech sectors since its $R \& D$ activities are largely supported by the government, which is also the case for European aerospace manufacturing. The high-tech sectors are: drugs (SIC 283), office and computing (SIC 357), communications equipment (SIC 366), electronic components (SIC 367), scientific instruments (SIC 382), medical instruments (SIC 384), and software (SIC 737).

The sample of this paper is constructed from the Compustat Global database. The countries included in the sample are: Belgium, Denmark, Finland, France, Germany, the Netherlands, Norway, Sweden, Switzerland, and the United Kingdom. A firm is considered to belong to a certain country based on its "country of incorporation" in the Compustat Global database. The sample covers 1995-2004, compared to BFP's (2009) sample period of 1990 to 2004. I exclude firms outside the seven high technology sectors and also high-tech firms which have no R\&D expenditure during the sample period. Following these screening criteria, Compustat Global has data of roughly 700 R\&D reporting high-tech firms incorporated in the 10 countries mentioned above. 280 of those are incorporated in the U.K., which constitute about 40 percent of the sample. I further exclude firms if their sum of cash flow to assets ratio is negative, in line with BFP (2009). Firms with negative sums of cash flow to assets are generally outliers. Conducting this additional screen makes my results more comparable to BFP's (2009).

BFP (2009) divide their sample into "young" and "mature" firms. Their definitions of "young" and "mature" are based on the number of years since the firm's stock price first appears in Compustat North America. A firm is classified as "young" within the first 15 years after its first appearance in the database and classified as "mature" thereafter. I try to emulate

\footnotetext{
$\overline{{ }^{2} \text { See BFP (2009, p. 163, footnote 8). }}$
} 
this procedure as much as possible. Since I only have data for 1995 to 2004 I classify a firm as "new" if it had its IPO after the first year of the sample period, i.e. the IPO took place after 1995. A firm is classified as "old" if it is covered in the sample in 1995.

All variables are scaled by beginning of the period total assets and the key ratios are then trimmed at the one percent level for outliers. The variables used in the empirical analysis are described in the appendix.

\subsection{Descriptive statistics}

Due to the vastly different financial systems of the U.K. and the other nine European countries I examine the U.K. separately. I refer to the remaining nine European countries as the Continental European sample.

[Figure 1 about here]

In figure $1 \mathrm{R} \& \mathrm{D}$ to total assets are presented for U.K., high-tech firms in the top graph and for Continental European firms in the bottom graph. Both graphs display heterogeneity regarding new and old firms. The new firms appear to diverge from the old firms for both samples in 1998. The pattern looks similar for both the U.K. and the Continental European sample, however the new, U.K., high-tech firms peak at about 0.200 compared to their Continental European counterparts of 0.160 . The development of old, high-tech firms' R\&D to assets is virtually flat and somewhat declining during the sample period for both subsamples. New, U.K., high-tech firms recorded R\&D ratios of $0.188,0.207$ and 0.197 from 1998-2000 compared to 0.103, 0.155 and 0.159 for their Continental European counterparts. 
So, even though the graphs in figure 1 appear similar, the size of the R\&D ratios for new, U.K. and, Continental European, high-tech firms differs.

[Figure 2 about here]

The U.K., high-tech sample does not display much heterogeneity in the cash flow variable. Both old and new, U.K., high-tech firms experienced a boom in internal equity at the beginning of the sample period and a subsequent decline towards the end. In the continental European sample, new, high-tech firms experienced a rise in cash flow starting from 1996, which then fell back to its 1995 level in 2001 during the recession. Old, Continental European, high-tech firms, on the other hand, are fairly consistent around 0.200 besides a small dip in connection to the recession at the beginning of the 2000s.

[Figure 3 about here]

Due to the stock price increases of the late 1990s the supply of external equity also experienced an upward shift. Both U.K. and Continental European, new, high-tech firms experienced a boom in net stock issuance normalized by assets from 1998-2000. The U.K. firms' peak was in 2000 at 1.031 compared to 0.703 for Continental European, high-tech firms. The external equity ratios plummeted in 2001 following the bust of the IT-bubble. For new, Continental European firms the drop was from 0.703 to 0.092 . The drop for new, U.K. firms was also significant, from the peak of 1.031 to 0.413 . Old, high-tech firms did not experience similar supply shifts. The external equity ratio for Continental European, hightech firms, new as well as old, remained near zero from 2001 and onwards. 
[Table 1 and 2 about here]

The development of R\&D, cash flow and net stock issuance (normalized by beginning of the period total assets) for both samples resembles what took place in the U.S. during the same period. Table 1 contains descriptive statistics for the U.K., high-tech sample and table 2 for the Continental European sample. The peak years, 1998-2000, of net stock issuance are well above the overall average for both the U.K. and the Continental European samples. The average net stock issuance of new, U.K. firms is 0.333 compared to 1.031 in 1999 . In both tables 1 and 2 there is heterogeneity between the new and old sub-samples. There are some noteworthy similarities and dissimilarities from comparing the European results to BFP's (2009) U.S. sample. ${ }^{3}$ In the U.K. sample the R\&D intensity reported is virtually identical to that of the U.S., high-tech sample. Young, U.S., high-tech firms had an R\&D to assets average of 0.194 and mature firms had a 0.098 average. In the U.K. this average is 0.194 for the new firms and 0.094 for the old firms. The Continental European, high-tech firms are less R\&D intensive, but they display the same type of heterogeneity in terms of new and old firms. New, Continental European high-tech firms had an R\&D intensity of 0.136 and old firms an intensity of 0.077 . In terms of cash flow, new, U.K. firms' average is higher than for old firms, 0.215 compared to 0.179 , again almost identically to the U.S. sample in BFP (2009). The Continental European sample has a reversed pattern with a higher ratio for the old firm sub-sample. U.K., high-tech firms differ in terms of external equity dependence compared to U.S. firms. The new U.K. sample displays high external equity dependence, similarly to young, U.S. firms. However, old, U.K. high-tech firms are also external equity dependent, albeit much less so than their new firm counterparts. In BFP's (2009) U.S. sample, the mature firms make use of very little external equity. The Continental European, high-tech

\footnotetext{
${ }^{3}$ See BFP (2009, p. 166: table I)
} 
firms resemble the U.S. more in terms of external equity use. Old, Continental European, high-tech firms have a net stock ratio as low as that of the U.S., mature firms. New, Continental European, high-tech firms on the other hand have a net stock ratio of 0.220 . This ratio for new, U.K., high-tech firms is 0.333 and for young, U.S. firms is 0.268 .

The graphical and descriptive analysis shows that new, high-tech firms in Europe experienced a supply shift in equity finance which coincided with a rise in R\&D intensity during the late 1990s and a subsequent decline in equity supply and R\&D intensity in the early 2000s. New, U.K., high-tech firms appear to have experienced a greater equity supply shift and subsequent increase in R\&D intensity than new, Continental European firms. This is formally examined in the Econometric results section.

\section{Econometric results}

This section presents one-step systems GMM estimates of dynamic Euler equation models. BFP (2009) use one-step first difference GMM instead. I prefer the systems GMM approach since the orthogonal transformation preserves sample size if there are gaps in the data and allows more instruments to be used which improves the precision of the estimates. Arellano and Bond (1991) suggest using one-step GMM since it is less plagued with finite sample bias compared to the two-step estimates. The main results are instrumented with t-3 and t-4 level values for the differenced equation and $\mathrm{t}-2$ lagged differences for the level equation which allows the error structure to be an MA-(1) process. I evaluate the instruments' validity with AR-(1) and AR-(2) tests testing the null hypothesis of no serial autocorrelation and the Hansen and Sargan tests which are chi square distributed under the null hypothesis of exogenous instruments. 


\subsection{Pooled sample results}

Columns 1 and 2 of table 3 contain the Baseline Euler estimates for the pooled samples comprising all U.K., high-tech firms and all Continental European, high-tech firms respectively.

[Table 3 about here]

The U.K. sample has lagged R\&D estimates corroborating the baseline Euler model, around positive 1 for the lagged $R \& D$ variable and around negative 1 for the lagged quadratic $R \& D$ variable. However, the required negative lagged cash flow estimate is neither present for the U.K. nor the Continental European pooled sample. For both sub-samples there is first order serial autocorrelation but the AR (2)-test cannot reject the null hypothesis of second order serial autocorrelation.

The augmented Euler equation model is applied to both samples and the results are presented in columns 3 and 4 of table 3 . The pooled U.K. results are very similar to the U.S. results in BFP (2009). There are jointly significant cash flow and external equity effects at below 1 percent. The size of the contemporaneous cash flow and net stock issuance estimates are similar to the U.S. results of BFP (2009). The pooled Continental European sample does not display any external equity effect. Next I split the sample on new and old firms.

\subsection{New and old firm estimates}


[Table 4 about here]

In table 4 the estimates of old, U.K. and old, Continental European, high-tech firms are presented in columns 1 and 2. There are less financial variable correlations when examining the old, high-tech firms individually, in line with the evidence from figures 1-3. The old firm samples are close to the target values of positive 1 for lagged $R \& D$ and negative 1 for lagged quadratic R\&D, especially the old, Continental European sample. The Continental European, old, high-tech firms have a jointly significant net stock effect, but it is negative.

Estimates for the new, high-tech firms are compiled in columns 3 and 4 of table 4 . The new, Continental European, sample rejects the baseline Euler equation model mostly due to the small size of especially the lagged quadratic R\&D variables, falling from -0.668 to -0.144 . The lagged R\&D variables are qualitatively unchanged for the new, U.K., high-tech sample but this sample displays clear financial effects ultimately rejecting the baseline Euler equation model. The financial variable estimates for new, high-tech firms corroborate the graphical evidence of figures 1-3. The joint cash flow effect for new, U.K., high-tech firms is not significant at conventional levels, but it is significant at below 10 percent. The new, Continental European high-tech firms on the other hand display a significant joint cash flow effect. In terms of external equity, new, U.K., high-tech firms display a clearly significant relationship with $R \& D$ to assets. New, Continental European, high-tech firms do not share this relationship. A finding which is highly plausible due to the different financial systems of the U.K. and the U.S. compared to Continental European countries.

\subsection{Robustness}


[Table 5 about here]

I have conducted a number of alternative sample splits previously used in the literature to test the robustness of the results of section 4.2. In table 5 the sample is split at the median of average employment. Firms at or below the median of average employment are considered small and firms above the median are considered large (amongst others: Gertler and Hubbard, 1989; Kim et al., 1998; Almeida et al., 2004; use firm size as proxy for external finance access). For the Continental European sample it seems as if some of the firms classified as new are also large firms since the joint cash flow estimate is significant for large firms and not for small firms. Otherwise, this split corroborates the new/old sample split reasonably well. This split actually appears to provide a cleaner split of the sample. Both the U.K. and Continental European, large firm sample corroborate the initial Euler equation model without financial variables. Both lagged $R \& D$ and lagged quadratic $R \& D$ meet their target values. Neither cash flow nor external equity is jointly significant for large, U.K., high-tech firms which imply less binding financing constraints. Large, continental European firms on the other hand display R\&D investment-cash flow sensitivity both contemporaneously and jointly. The small firm samples for both the U.K. and Continental Europe reject the null hypothesis in terms of not meeting the target values of the baseline Euler equation model. Especially the U.K., small, high-tech firm sample displays large financial variable effects corroborating the new firm split in section 4.2.

The sample is also split based on whether the firm pays dividend or not (e.g. Fazzari et al., 1988; Hubbard et al., 1995; Gilchrist and Himmelberg, 1995) and whether the firm is above or below the median of average cash flow volatility (e.g. Bates et al., 2008). Firms which do 
not pay dividend and are above the median of average cash flow volatility are considered more likely to be financially constrained. The regression results following these two additional splits supply similar evidence as the small/large split in table 5. Non-dividend paying firms and firms with above the median cash flow volatility display joint equity dependence for U.K., high-tech firms but not for Continental European, high-tech firms, also in line with the new firm estimates in table 4.

[Table 6 about here]

In table 6 I present additional GMM-estimators as further robustness of the pooled U.K. and Continental European results for the Euler equation model with financial variables originally estimated with one-step systems GMM in table 3. One-step first difference GMM estimates are presented in columns 1 and 3 of table 6. First difference GMM is mentioned in the literature to suffer from a weak instrument problem due to the fact that it is only possible to use lagged level values as instruments which leads to imprecise estimates (Mairesse et al., 1999; Allonso-Borrego and Arellano, 1999). The first difference GMM estimates are clearly generating less precise estimates for the U.K. sample. Both joint effects are no longer significant. The contemporaneous effects are also smaller in magnitude as well as having larger standard errors. The Continental European sample is less obviously affected by the first difference GMM-estimator. The two-step systems GMM-estimator with Windmeijer corrected standard errors, presented in columns 2 and 4 of table 6 , are very close to the onestep estimates of table 3. Considering alternative lag lengths of the original one-step systems GMM estimates does not affect the results very much. 
The results obtained in this section with one-step systems GMM appear to be robust to the choice of GMM-estimator and lag length of the instruments.

\section{Summary and implications}

I estimate dynamic Euler equation models for U.K. and Continental European, high-tech firms separately. I find that new, U.K., high-tech firms experienced a supply shift in both internal and external equity during the late 1990s which enabled them to invest more in R\&D resulting in increasing $R \& D$ intensities. New, Continental European, high-tech firms only experienced a supply shift in cash flow and not in external equity resulting in lower R\&D intensities than for their U.K. counterparts. Both the U.K. and Continental European, hightech firms experienced increasing equity ratios and $R \& D$ ratios during the booming economy of the late 1990s but U.K., high-tech firms had higher ratios in terms of both net raised external equity to assets and R\&D to assets than Continental European, high-tech firms.

The U.K. regression results are very similar to BFP's (2009) findings for the U.S. Brown and Petersen (2009) argue that equity market improvements have enabled young, U.S. firms to raise their share of $R \& D$ out of total investment during the period 1970-2006. A plausible explanation for the lacking external equity effect for Continental European countries is that their equity markets are less developed than in the U.S. and U.K.

The findings of this paper open avenues for future research. The financing of $R \& D$ is potentially a link through which financial development affects economic growth. The findings here suggest that a market based financial system supplies public equity to $R \& D$ intensive firms otherwise facing difficulties obtaining external finance. By improving the 
depth of their equity markets, Continental European countries may very well facilitate the financing of high-tech firm $R \& D$ and fuel economic growth by relaxing financing constraints.

\section{Appendix: The variables and their Compustat Global abbreviations}

$r d_{t}$ : Research and development expenditure in period $\mathrm{t}(\mathrm{XRD})$ normalized by beginning of the period book value of total assets (AT).

$Y_{t}$ : Net sales in period $\mathrm{t}$ (SALE) normalized by beginning of the period book value of total assets (AT).

$\mathrm{CF}_{\mathrm{t}}$ : Gross cash flow in period $\mathrm{t}$ normalized by beginning of the period book value of total assets (AT). Gross cash flow is defined as after-tax income before extraordinary items (IB) plus depreciation and amortization (DP) plus research and development expenditure (XRD).

$s t k_{t}$ : Net cash raised from stock issues normalized by beginning of the period book value of total assets (AT). Net cash from stock issues is defined as the sale of common and preferred stock (SSTK) minus the purchase of common and preferred stock (PRSTK).

$d b t_{t}$ : New long-term debt (DLTT) in period t normalized by beginning of the period book value of total assets (AT). New long-term debt is defined as the difference between long-term debt in period $\mathrm{t}$ and long-term debt in period $\mathrm{t}-1$.

\section{References}

Aghion, P., Howitt, P., 1992. A Model of Growth through Creative Destruction, Econometrica 60, 323-351.

Aghion, P., Howitt, P., 1998. Endogenous Growth Theory. Cambridge, MA: MIT Press. 
Almeida, H., Campello, M., Weisbach, M., 2004. The Cash Flow Sensitivity of Cash, Journal of Finance 59, 1777-1804.

Alonso-Borrego, C., Arellano, M., 1999. Symmetrically Normalized Instrumental Variable Estimation Using Panel Data, Journal of Business and Economic Statistics 17, 36-49.

Arellano, M., Bond, S., 1991. Some tests of specification of panel data: Monte Carlo evidence and an application to employment equations, Review of Economic Studies 58, 277-297.

Bates, T. W., Kahle, K. M., Stulz, R. M., 2008. Why do U.S. Firms Hold so Much More Cash Than They Used To?, Journal of Finance, forthcoming.

Beck, T., Levine, R., 2002. Industry Growth and Capital Allocation: Does having a marketor bank-based system matter? Journal of Financial Economics 64, 147-180.

Bond, S., Meghir, C., 1994. Dynamic Investment Models and the Firm's Financial Policy, Review of Economic Studies 61, 197-222.

Bond, S., 2002. Dynamic panel data models: A guide to micro data methods and practice, Portuguese Economic Journal 1, 141-162.

Brown, J. R., Fazzari, S. M., Petersen, B. C., 2009. Financing Innovation and Growth: Cash Flow, External Equity, and the 1990s R\&D Boom, Journal of Finance 64, 151-18.

Brown, J. R., Petersen, B. C., 2009. Why has the investment-cash flow sensitivity declined so sharply? Rising R\&D and equity market developments, Journal of Banking \& Finance $33,971-984$.

Carpenter, R. E., Petersen, B. C., 2002. Capital Market Imperfections, High-Tech Investment, and New Equity Financing, Economic Journal 112, 54-72.

Fazzari, S. M., Hubbard, R. G., Petersen, B. C., 1988. Financing Constraints and Corporate Investment, Brookings Papers on Economic Activity 1, 141-195.

Gertler, M., Hubbard, R. G., 1989. Financing Factors in Business Fluctuations, NBER Working Paper W2758. 
Gilchrist, S., Himmelberg, C. P., 1995. Evidence on the Role of Cash Flow for Investment, Journal of Monetary Economics 36, 541-572.

Hall, B. H., 2002. The Financing of Research and Development, Oxford Review of Economic Policy 18, 35-51.

Himmelberg, C. P., Petersen, B. C., 1994. R\&D and Internal Finance: A Panel Study of Small Firms in High-Tech Industries, Review of Economics and Statistics 76, 38-51.

Hubbard, R. G., Kashyap, A. K., Whited, T. M., 1995. Internal Finance and Firm Investment, Journal of Money, Credit and Banking 27, 683-701.

Kim, C. S., Mauer, D. C., Sherman, A. E., 1998. The Determinants of Corporate Liquidity: Theory and Evidence, Journal of Financial and Quantitative Analysis 33, 335-359.

Mairesse, J., Hall, B. H., and Mulkaly, B., 1999. Firm-Level Investment in France and the United States: An Exploration of What We Have Learned in Twenty Years, Annales d'Economie et de Statistique 55/56, 27-67.

Roodman, D., 2006. How to do xtabond2: An Introduction to "Difference" and "System" GMM in Stata, CGDEV Working paper 103.

Roodman, D., 2008. A Note on the Theme of Too Many Instruments, CGDEV Working Paper 125. 
Figure 1 - Average R\&D to total assets ratios for old, and new, U.K., high-tech firms (top graph) and Continental European, high-tech firms (bottom graph).

R\&D scaled by beginning of the period total assets for U.K., high-tech firms in the upper graph and Continental European, high-tech firms in the bottom graph. The full line represents new, high-tech firms (a firm is considered new if it had its IPO after 1995), and the dashed line represents old, high-tech firms (a firm present at the beginning of the sample period is considered old).

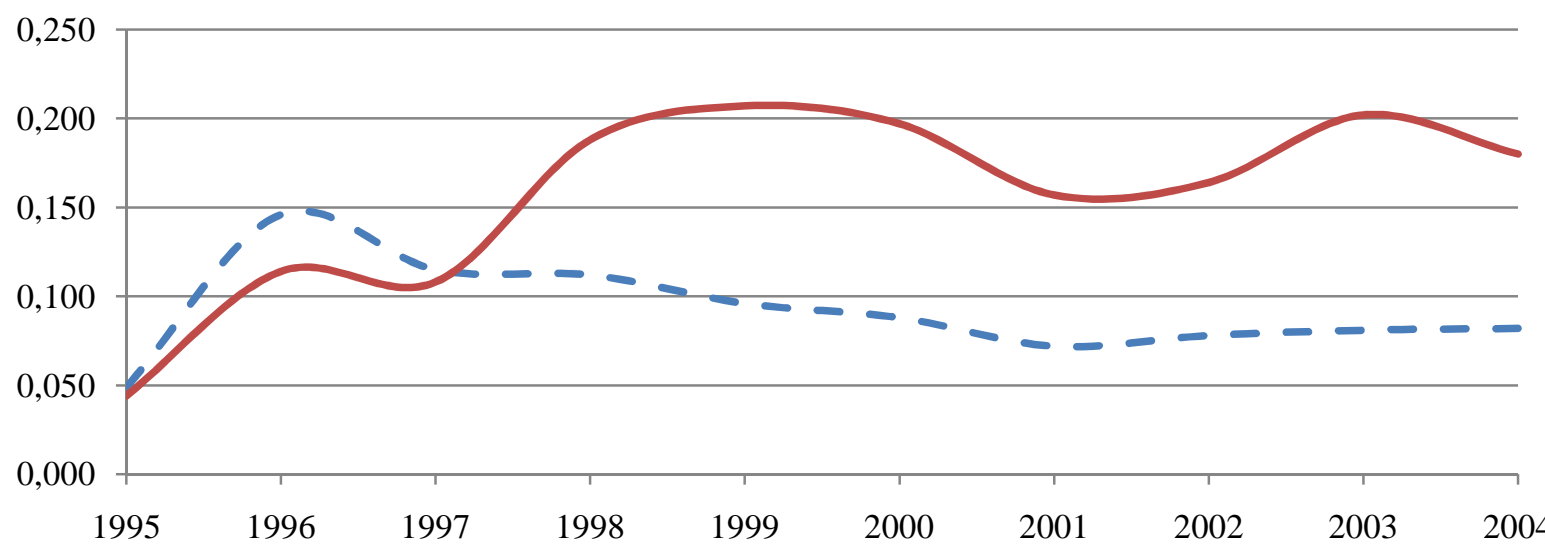

- Old, U.K., High-tech firms (R\&D) — New, U.K., high-tech firms (R\&D)

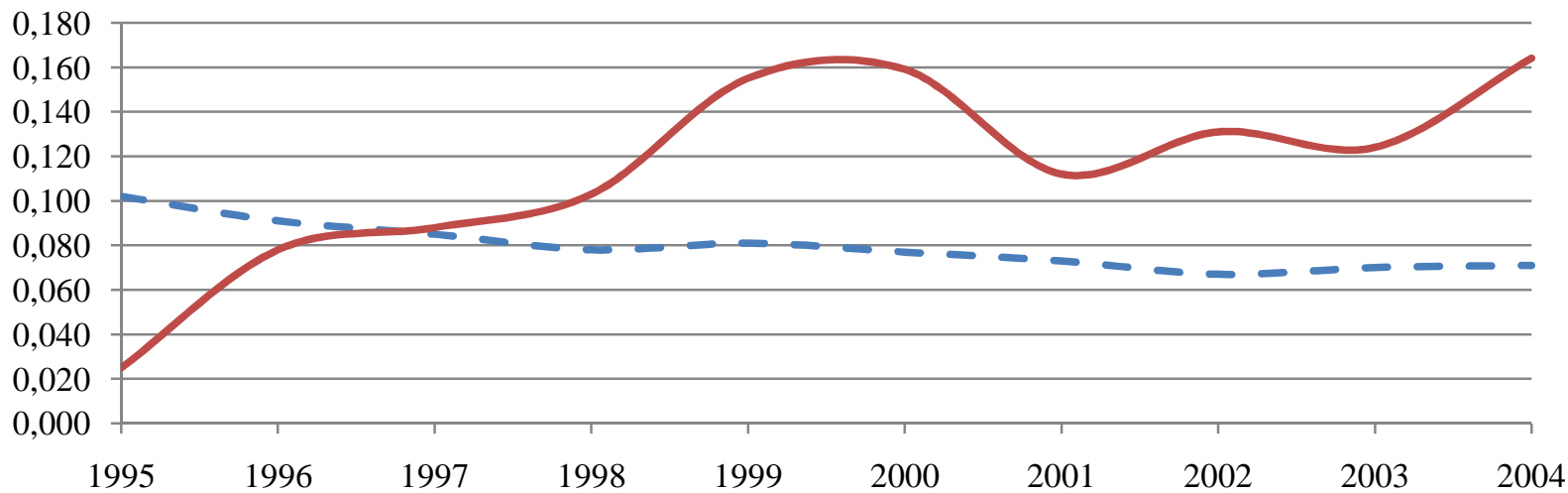

- Old, Continental European, high-tech firms (R\&D)

New, Continental European, high-tech firms (R\&D) 
Figure 2 - Average Cash flow to total assets ratios for old, and new, U.K., high-tech firms (top graph) and Continental European, high-tech firms (bottom graph).

Cash flow scaled by beginning of the period total assets for U.K., high-tech firms in the upper graph and Continental European, high-tech firms in the bottom graph. The full line represents new, high-tech firms (a firm is considered new if it had its IPO after 1995), and the dashed line represents old, high-tech firms (a firm present at the beginning of the sample period is considered old).

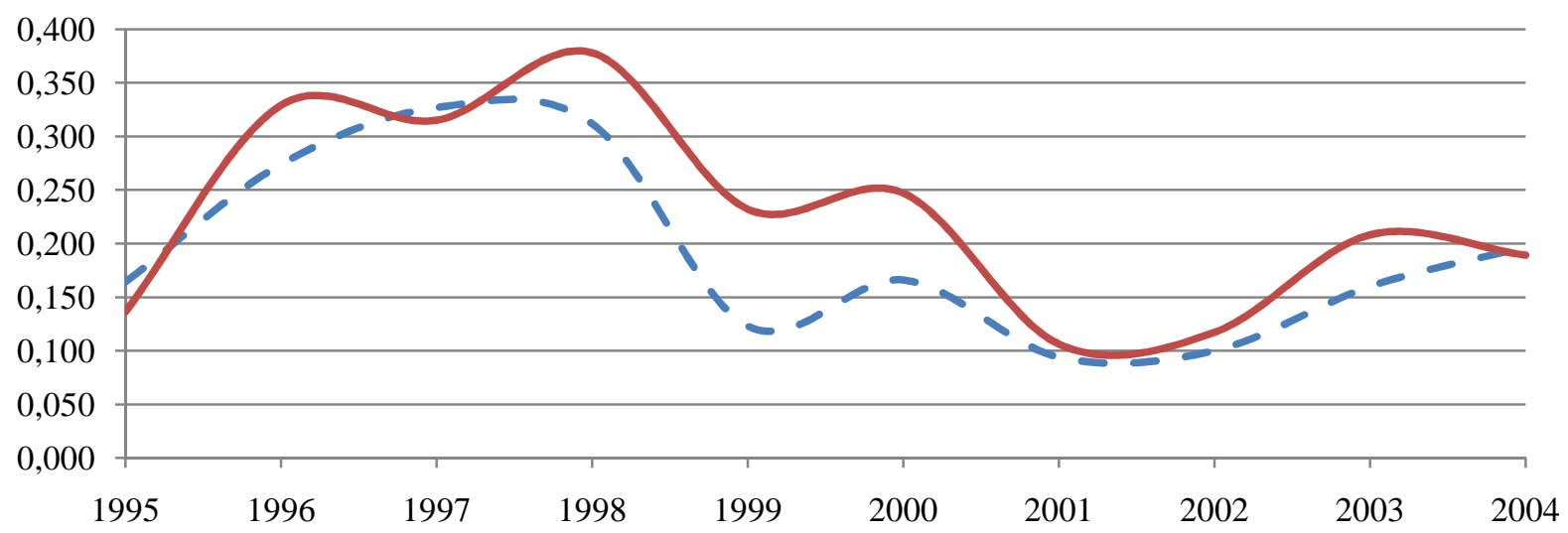

- Old, U.K., high-tech firms (Cash flow) — New, U.K., high-tech firms (Cash flow)

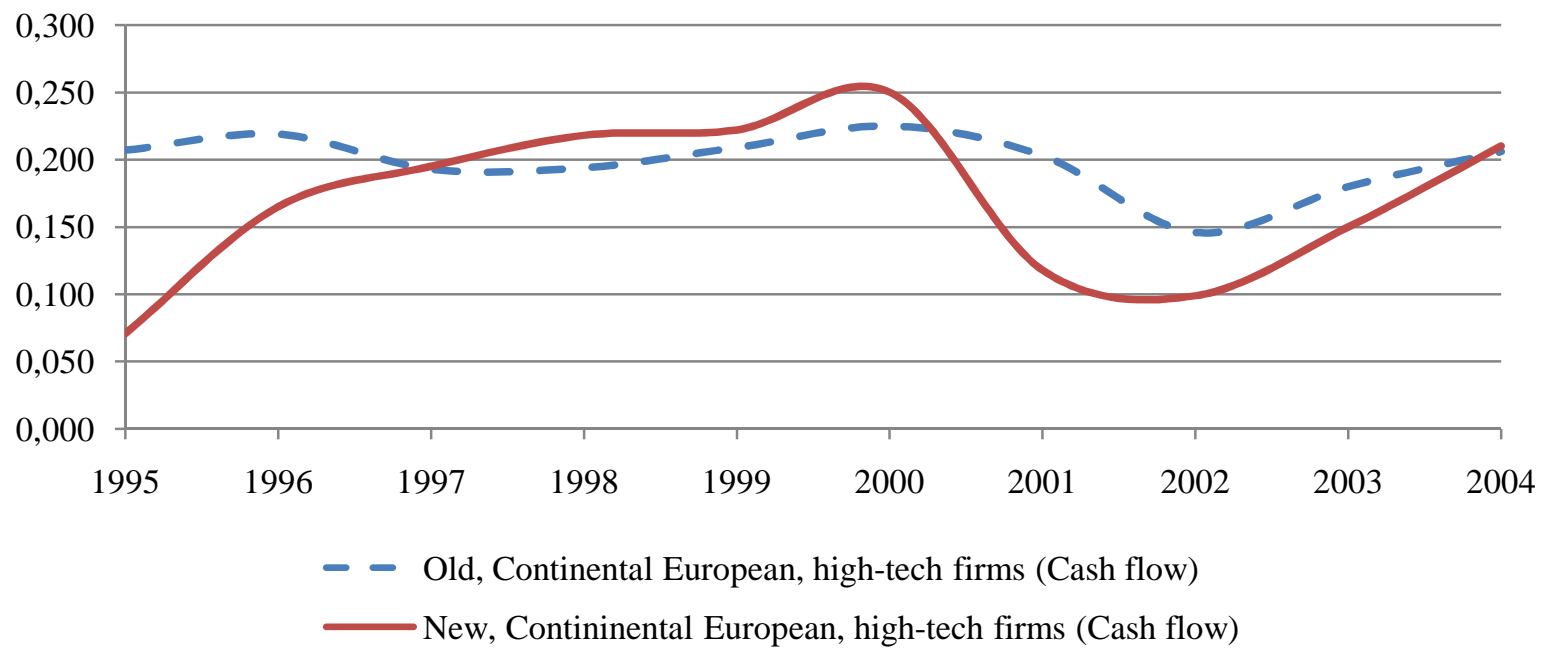


Figure 3 - Average net stock issuance to total assets for old, and new, U.K., high-tech firms (top graph) and Continental European, high-tech firms (bottom graph).

Net stock issuance scaled by beginning of the period total assets for U.K., high-tech firms in the upper graph and Continental European, high-tech firms in the bottom graph. The full line represents new, high-tech firms (a firm is considered new if it had its IPO after 1995), and the dashed line represents old, high-tech firms (a firm present at the beginning of the sample period is considered old).

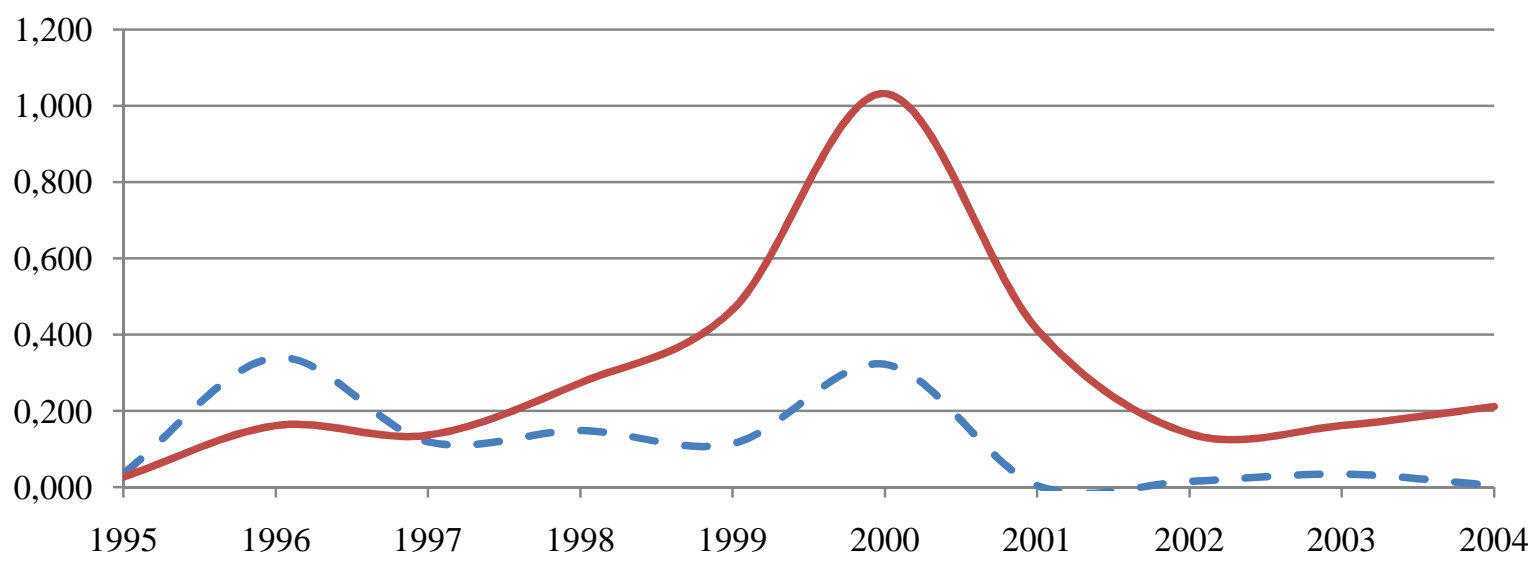

- Old, U.K., high-tech firms (Net stock) — New, U.K., high-tech firms (Net stock)

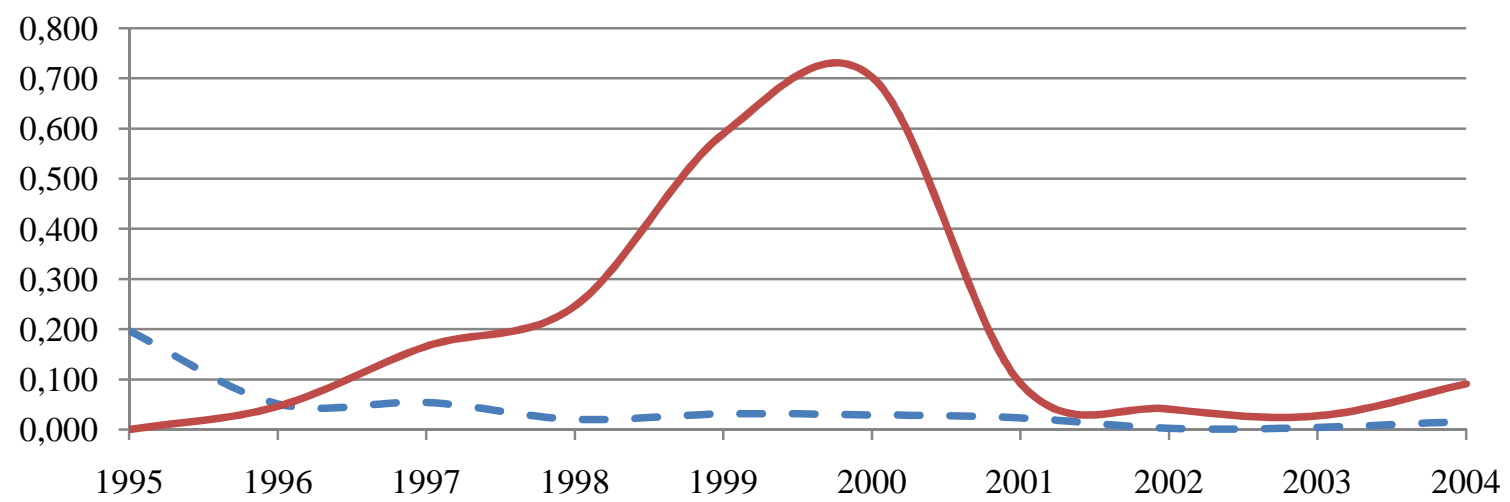

- Old, Continental European, high-tech firms (Net stock)

New, Continental European, high-tech firms (Net stock) 
Table 1 - Sample descriptive statistics for U.K., high-tech firms

Sample descriptive statistics for all U.K., high-tech firms in column 1 (the sectors considered high technology are SIC: 283, 357, 366, 367, 382, 384, and 737), for new, U.K., high-tech firms in column 2 (a firm is considered new if it had its IPO after 1995), and old, U.K., high-tech firms in column 3 (a firm present at the beginning of the sample period is considered old).

\begin{tabular}{|c|c|c|c|}
\hline $\begin{array}{l}\text { Variable and } \\
\text { Statistic }\end{array}$ & All U.K. firms & New firms & Old firms \\
\hline \multicolumn{4}{|l|}{$r d_{t}$} \\
\hline Mean & 0.170 & 0.194 & 0.094 \\
\hline $25^{\text {th }}$ & 0.061 & 0.069 & 0.045 \\
\hline Median & 0.111 & 0.131 & 0.080 \\
\hline $75^{\text {th }}$ & 0.210 & 0.235 & 0.114 \\
\hline SD & 0.192 & 0.212 & 0.067 \\
\hline \multicolumn{4}{|l|}{$C F_{t}$} \\
\hline Mean & 0.207 & 0.215 & 0.179 \\
\hline $25^{\text {th }}$ & 0.076 & 0.065 & 0.100 \\
\hline Median & 0.181 & 0.186 & 0.175 \\
\hline $75^{\text {th }}$ & 0.327 & 0.353 & 0.278 \\
\hline SD & 0.238 & 0.256 & 0.160 \\
\hline \multicolumn{4}{|l|}{ Stk $_{t}$} \\
\hline Mean & 0.290 & 0.333 & 0.119 \\
\hline $25^{\text {th }}$ & 0.000 & 0.000 & 0.000 \\
\hline Median & 0.003 & 0.003 & 0.002 \\
\hline $75^{\text {th }}$ & 0.094 & 0.156 & 0.011 \\
\hline SD & 1.035 & 1.136 & 0.426 \\
\hline \multicolumn{4}{|l|}{$Y_{t}$} \\
\hline Mean & 1.261 & 1.293 & 1.134 \\
\hline $25^{\text {th }}$ & 0.677 & 0.665 & 0.729 \\
\hline Median & 1.143 & 1.160 & 1.029 \\
\hline $75^{\text {th }}$ & 1.562 & 1.588 & 1.474 \\
\hline SD & 1.005 & 1.085 & 0.577 \\
\hline \multicolumn{4}{|l|}{$d b t_{t}$} \\
\hline Mean & 0.081 & 0.080 & 0.088 \\
\hline $25^{\text {th }}$ & 0.000 & 0.000 & 0.000 \\
\hline Median & 0.009 & 0.007 & 0.016 \\
\hline $75^{\text {th }}$ & 0.076 & 0.074 & 0.094 \\
\hline SD & 0.175 & 0.171 & 0.187 \\
\hline
\end{tabular}


Table 2 - Sample descriptive statistics for Continental European, high-tech firms

Sample descriptive statistics for all Continental European, high-tech firms in column 1 (the sectors considered high technology are SIC: 283, 357, 366, 367, 382, 384, and 737), for new, Continental European, high-tech firms in column 2 (a firm is considered new if it had its IPO after 1995), and old, Continental European, high-tech firms in column 3 (a firm present at the beginning of the sample period is considered old).

\begin{tabular}{|c|c|c|c|}
\hline $\begin{array}{l}\text { Variable and } \\
\text { Statistic }\end{array}$ & $\begin{array}{l}\text { All Continental } \\
\text { European firms }\end{array}$ & New firms & Old firms \\
\hline \multicolumn{4}{|l|}{$r d_{t}$} \\
\hline Mean & 0.125 & 0.136 & 0.077 \\
\hline $25^{\text {th }}$ & 0.048 & 0.053 & 0.042 \\
\hline Median & 0.089 & 0.101 & 0.067 \\
\hline $75^{\text {th }}$ & 0.158 & 0.169 & 0.096 \\
\hline SD & 0.135 & 0.146 & 0.048 \\
\hline \multicolumn{4}{|l|}{$C F_{t}$} \\
\hline Mean & 0.182 & 0.179 & 0.196 \\
\hline $25^{\text {th }}$ & 0.078 & 0.066 & 0.121 \\
\hline Median & 0.167 & 0.160 & 0.182 \\
\hline $75^{\text {th }}$ & 0.269 & 0.272 & 0.261 \\
\hline SD & 0.195 & 0.208 & 0.125 \\
\hline \multicolumn{4}{|l|}{ Stk $_{t}$} \\
\hline Mean & 0.185 & 0.220 & 0.025 \\
\hline $25^{\text {th }}$ & 0.000 & 0.000 & 0.000 \\
\hline Median & 0.000 & 0.000 & 0.000 \\
\hline $75^{\text {th }}$ & 0.019 & 0.034 & 0.004 \\
\hline SD & 0.809 & 0.887 & 0.104 \\
\hline \multicolumn{4}{|l|}{$Y_{t}$} \\
\hline Mean & 1.221 & 1.195 & 1.334 \\
\hline $25^{\text {th }}$ & 0.763 & 0.689 & 1.001 \\
\hline Median & 1.104 & 1.051 & 1.289 \\
\hline $75^{\text {th }}$ & 1.488 & 1.464 & 1.561 \\
\hline SD & 0.899 & 0.963 & 0.520 \\
\hline \multicolumn{4}{|l|}{$d b t_{t}$} \\
\hline Mean & 0.110 & 0.106 & 0.126 \\
\hline $25^{\text {th }}$ & 0.005 & 0.003 & 0.027 \\
\hline Median & 0.060 & 0.050 & 0.111 \\
\hline $75^{\text {th }}$ & 0.155 & 0.146 & 0.184 \\
\hline SD & 0.153 & 0.159 & 0.119 \\
\hline
\end{tabular}


Table 3 - Dynamic R\&D regressions: The baseline and augmented Euler equation model

Dynamic R\&D regressions on the U.K., high-tech sample (columns 1 and 3) and the Continental European, high-tech sample (columns 2 and 4) are estimated with one-step systems GMM. Columns 1 and 2 are estimates from running the baseline Euler equation model assuming no financing constraints and columns 3 and 4 are estimates from running the augmented Euler equation model with financial variables testing for financing constraints.

\begin{tabular}{|c|c|c|c|c|}
\hline $\begin{array}{l}\text { Dep. Variable: } \\
r d_{t}\end{array}$ & $\begin{array}{l}\text { Baseline Euler: } \\
\text { U.K. firms }\end{array}$ & $\begin{array}{l}\text { Baseline Euler: } \\
\text { Continental } \\
\text { European firms }\end{array}$ & $\begin{array}{l}\text { Euler w financial } \\
\text { variables: U.K. } \\
\text { firms }\end{array}$ & $\begin{array}{c}\text { Euler w financial } \\
\text { variables: } \\
\text { Continental } \\
\text { European firms }\end{array}$ \\
\hline$r d_{t-1}$ & $\begin{array}{c}1.437 * * * \\
(0.321)\end{array}$ & $\begin{array}{c}1.056^{* * *} \\
(0.308)\end{array}$ & $\begin{array}{c}1.142^{* * *} \\
(0.181)\end{array}$ & $\begin{array}{c}0.652 * * \\
(0.159)\end{array}$ \\
\hline$r d_{t-1}^{2}$ & $\begin{array}{c}-0.840 * * * \\
(0.214)\end{array}$ & $\begin{array}{c}-0.373^{*} \\
(0.213)\end{array}$ & $\begin{array}{c}-0.591 * * * \\
(0.107)\end{array}$ & $\begin{array}{c}-0.124 * \\
(0.070)\end{array}$ \\
\hline$Y_{t}$ & & & $\begin{array}{l}0.016 \\
(0.032)\end{array}$ & $\begin{array}{l}0.041 \\
(0.029)\end{array}$ \\
\hline$Y_{t-1}$ & $\begin{array}{c}-0.076 * * \\
(0.039)\end{array}$ & $\begin{array}{c}-0.029 * \\
(0.016)\end{array}$ & $\begin{array}{c}-0.072^{*} \\
(0.039)\end{array}$ & $\begin{array}{c}-0.047 * * \\
(0.023)\end{array}$ \\
\hline $\mathbf{C F}_{t}$ & & & $\begin{array}{l}0.132 \\
(0.082)\end{array}$ & $\begin{array}{c}0.159 * * \\
(0.069)\end{array}$ \\
\hline $\mathrm{CF}_{t-1}$ & $\begin{array}{l}0.029 \\
(0.098)\end{array}$ & $\begin{array}{l}0.015 \\
(0.038)\end{array}$ & $\begin{array}{c}0.074 * * \\
(0.010)\end{array}$ & $\begin{array}{r}-0.050 \\
(0.041)\end{array}$ \\
\hline$s t k_{t}$ & & & $\begin{array}{c}0.194 * * * \\
(0.045)\end{array}$ & $\begin{array}{r}-0.019 \\
(0.058)\end{array}$ \\
\hline$s t k_{t-1}$ & & & $\begin{array}{c}-0.046 * * * \\
(0.018)\end{array}$ & $\begin{array}{l}0.014 \\
(0.033)\end{array}$ \\
\hline Observations & 367 & 900 & 352 & 825 \\
\hline Instruments & 87 & 87 & 87 & 87 \\
\hline CF Chi2 (p-value) & & & 0.001 & 0.062 \\
\hline Stk Chi2 (p-value) & & & 0.002 & 0.904 \\
\hline $\operatorname{AR}(1)$ & 0.014 & 0.003 & 0.015 & 0.001 \\
\hline$A R(2)$ & 0.272 & 0.529 & 0.754 & 0.962 \\
\hline Hansen & 0.578 & 0.450 & 0.635 & 0.186 \\
\hline Sargan & 0.000 & 0.002 & 0.000 & 0.191 \\
\hline
\end{tabular}

Note: All regressions are performed including time dummies.

Heteroskedasticity robust standard errors in parenthesis. ***, **, * indicate significance at 1,5 , and 10 percent respectively. One step systems GMM estimates.

Instruments differenced equation are lagged levels dated t-3 to t-4 and instruments level equation are lagged differences dated $\mathrm{t}-2$.

The Chi2 tests are tests of the null that the sum of current and lagged cash flow and net stock issuance respectively is zero.

The AR-tests are asymptotically normally distributed under the null hypothesis of no serial autocorrelation.

The Hansen and Sargan tests are chi-square distributed under the null of exogenous instruments. 
Table 4 - Dynamic R\&D regressions for separate new and old-firm samples

Dynamic R\&D regressions on the U.K., high-tech sample separated into old firms (column 1) and new firms (column 3) and the Continental European, high-tech sample separated into old firms (column 2) and new firms (column 4). The regressions are estimated with one-step systems GMM. A firm present at the beginning of the sample period is considered old and a firm is considered new if it had its IPO after 1995.

\begin{tabular}{|c|c|c|c|c|}
\hline $\begin{array}{l}\text { Dep. Variable: } \\
r d_{t}\end{array}$ & Old U.K. firms & $\begin{array}{l}\text { Old Continental } \\
\text { European firms }\end{array}$ & New U.K. firms & $\begin{array}{l}\text { New Continental } \\
\text { European firms }\end{array}$ \\
\hline$r d_{t-1}$ & $\begin{array}{c}1.012 * * * \\
(0.093)\end{array}$ & $\begin{array}{c}0.950 * * * \\
(0.225)\end{array}$ & $\begin{array}{c}1.195^{* * *} \\
(0.195)\end{array}$ & $\begin{array}{c}0.671 * * * \\
(0.166)\end{array}$ \\
\hline$r d_{t-1}^{2}$ & $\begin{array}{r}-0.475 \\
(0.417)\end{array}$ & $\begin{array}{r}-0.668 \\
(1.009)\end{array}$ & $\begin{array}{c}-0.621 * * * \\
(0.115)\end{array}$ & $\begin{array}{c}-0.144 * \\
(0.074)\end{array}$ \\
\hline$Y_{t}$ & $\begin{array}{c}0.043^{* * *} \\
(0.009)\end{array}$ & $\begin{array}{c}0.037 * * * \\
(0.010)\end{array}$ & $\begin{array}{l}0.034 \\
(0.032)\end{array}$ & $\begin{array}{l}0.038 \\
(0.031)\end{array}$ \\
\hline$Y_{t-1}$ & $\begin{array}{c}-0.048 * * * \\
(0.008)\end{array}$ & $\begin{array}{c}-0.038 * * * \\
(0.010)\end{array}$ & $\begin{array}{c}-0.071 * * \\
(0.039)\end{array}$ & $\begin{array}{c}-0.051^{* *} \\
(0.026)\end{array}$ \\
\hline $\mathbf{C F}_{t}$ & $\begin{array}{l}0.008 \\
(0.012)\end{array}$ & $\begin{array}{l}0.064 * \\
(0.034)\end{array}$ & $\begin{array}{l}0.142 * \\
(0.073)\end{array}$ & $\begin{array}{c}0.157^{* *} \\
(0.071)\end{array}$ \\
\hline $\mathrm{CF}_{t-1}$ & $\begin{array}{l}0.002 \\
(0.016)\end{array}$ & $\begin{array}{r}-0.021 \\
(0.030)\end{array}$ & $\begin{array}{l}0.037 \\
(0.083)\end{array}$ & $\begin{array}{r}-0.019 \\
(0.038)\end{array}$ \\
\hline$s t k_{t}$ & $\begin{array}{c}0.046^{* * *} \\
(0.012)\end{array}$ & $\begin{array}{c}-0.068 * * * \\
(0.024)\end{array}$ & $\begin{array}{c}0.194 * * * \\
(0.045)\end{array}$ & $\begin{array}{r}-0.004 \\
(0.060)\end{array}$ \\
\hline$s t k_{t-1}$ & $\begin{array}{c}-0.048 * * * \\
(0.016)\end{array}$ & $\begin{array}{c}-0.025^{*} \\
(0.013)\end{array}$ & $\begin{array}{c}-0.044 * * \\
(0.019)\end{array}$ & $\begin{array}{l}0.019 \\
(0.035)\end{array}$ \\
\hline Observations & 85 & 148 & 267 & 677 \\
\hline Instruments & 81 & 87 & 84 & 87 \\
\hline CF Chi2 (p-value) & 0.548 & 0.131 & 0.058 & 0.037 \\
\hline Stk Chi2 (p-value) & 0.845 & 0.000 & 0.001 & 0.728 \\
\hline$A R(1)$ & 0.021 & 0.017 & 0.013 & 0.002 \\
\hline$A R(2)$ & 0.423 & 0.123 & 0.531 & 0.939 \\
\hline Hansen & 1.000 & 1.000 & 0.993 & 0.522 \\
\hline Sargan & 0.052 & 0.000 & 0.000 & 0.350 \\
\hline
\end{tabular}

Note: All regressions are performed including time dummies.

Heteroskedasticity robust standard errors in parenthesis. ***, **, * indicate significance at 1,5 , and 10 percent respectively. One step systems GMM estimates.

Instruments differenced equation are lagged levels dated $t-3$ to $t-4$ and instruments level equation are lagged differences dated $\mathrm{t}-2$.

The Chi2 tests are tests of the null that the sum of current and lagged cash flow and net stock issuance respectively is zero. The AR-tests are asymptotically normally distributed under the null hypothesis of no serial autocorrelation.

The Hansen and Sargan tests are chi-square distributed under the null of exogenous instruments. 
Table 5 - Dynamic R\&D regressions for separate small- and large-firm samples

Dynamic R\&D regressions on the U.K., high-tech sample separated into large firms (column 1) and small firms (column 3) and the Continental European, high-tech sample separated into large firms (column 2) and small firms (column 4). The regressions are estimated with one-step systems GMM. A firm is considered large if it is above the median average employment during the sample period and subsequently considered small if it is at or below the median.

\begin{tabular}{|c|c|c|c|c|}
\hline $\begin{array}{l}\text { Dep. Variable: } \\
r d_{t}\end{array}$ & Large U.K. firms & $\begin{array}{l}\text { Large Continental } \\
\text { European firms }\end{array}$ & Small U.K. firms & $\begin{array}{c}\text { Small Continental } \\
\text { European firms }\end{array}$ \\
\hline$r d_{t-1}$ & $\begin{array}{c}1.146 * * * \\
(0.260)\end{array}$ & $\begin{array}{c}1.147 * * * \\
(0.113)\end{array}$ & $\begin{array}{c}1.100 * * * \\
(0.155)\end{array}$ & $\begin{array}{c}0.745^{* * *} \\
(0.183)\end{array}$ \\
\hline$r d_{t-1}^{2}$ & $\begin{array}{c}-1.069 * \\
(0.556)\end{array}$ & $\begin{array}{c}-1.028 * * * \\
(0.336)\end{array}$ & $\begin{array}{c}-0.539 * * * \\
(0.101)\end{array}$ & $\begin{array}{c}-0.189 * * \\
(0.083)\end{array}$ \\
\hline$Y_{t}$ & $\begin{array}{c}0.046 * \\
(0.024)\end{array}$ & $\begin{array}{l}0.013 \\
(0.019)\end{array}$ & $\begin{array}{r}-0.043 \\
(0.055)\end{array}$ & $\begin{array}{l}0.032 \\
(0.030)\end{array}$ \\
\hline$Y_{t-1}$ & $\begin{array}{c}-0.045 * * \\
(0.021)\end{array}$ & $\begin{array}{r}-0.027 \\
(0.017)\end{array}$ & $\begin{array}{r}-0.033 \\
(0.040)\end{array}$ & $\begin{array}{c}-0.047 * \\
(0.026)\end{array}$ \\
\hline $\mathrm{CF}_{t}$ & $\begin{array}{c}0.091 * * \\
(0.041)\end{array}$ & $\begin{array}{c}0.156 * * * \\
(0.047)\end{array}$ & $\begin{array}{c}0.242 * * * \\
(0.065)\end{array}$ & $\begin{array}{l}0.113^{*} \\
(0.061)\end{array}$ \\
\hline $\mathrm{CF}_{t-1}$ & $\begin{array}{r}-0.031 \\
(0.040)\end{array}$ & $\begin{array}{c}0.084 * \\
(0.049)\end{array}$ & $\begin{array}{l}0.023 \\
(0.088)\end{array}$ & $\begin{array}{r}-0.045 \\
(0.039)\end{array}$ \\
\hline$s t k_{t}$ & $\begin{array}{l}0.004 \\
(0.022)\end{array}$ & $\begin{array}{c}0.070 * \\
(0.047)\end{array}$ & $\begin{array}{c}0.200 * * * \\
(0.035)\end{array}$ & $\begin{array}{l}0.069 \\
(0.047)\end{array}$ \\
\hline$s t k_{t-1}$ & $\begin{array}{r}-0.006 \\
(0.014)\end{array}$ & $\begin{array}{c}-0.017 * * \\
(0.008)\end{array}$ & $\begin{array}{c}-0.072 * * * \\
(0.023)\end{array}$ & $\begin{array}{l}0.015 \\
(0.033)\end{array}$ \\
\hline Observations & 186 & 536 & 166 & 289 \\
\hline Instruments & 87 & 87 & 77 & 76 \\
\hline CF Chi2 (p-value) & 0.152 & 0.007 & 0.000 & 0.307 \\
\hline Stk Chi2 (p-value) & 0.959 & 0.114 & 0.005 & 0.108 \\
\hline$A R(1)$ & 0.128 & 0.000 & 0.253 & 0.002 \\
\hline $\operatorname{AR}(2)$ & 0.062 & 0.623 & 0.522 & 0.197 \\
\hline Hansen & 1.000 & 0.312 & 1.000 & 0.863 \\
\hline Sargan & 0.999 & 0.212 & 0.002 & 0.391 \\
\hline
\end{tabular}

Note: All regressions are performed including time dummies.

Heteroskedasticity robust standard errors in parenthesis. ***, **, * indicate significance at 1, 5, and 10 percent respectively. One step systems GMM estimates.

Instruments differenced equation are lagged levels dated $t-3$ to $t-4$ and instruments level equation are lagged differences dated $\mathrm{t}-2$.

The Chi2 tests are tests of the null that the sum of current and lagged cash flow and net stock issuance respectively is zero.

The AR-tests are asymptotically normally distributed under the null hypothesis of no serial autocorrelation.

The Hansen and Sargan tests are chi-square distributed under the null of exogenous instruments. 
Table 6 - Dynamic R\&D regressions for the pooled samples: Robustness

Dynamic R\&D regressions corresponding to the one-step systems GMM results in table 3 on the Euler equation model with financial variables (Columns 3 and 4) are estimated with one-step first difference GMM and two-step systems GMM. The two-step systems GMM results are estimated with Windmeijer corrected standard errors.

\begin{tabular}{|c|c|c|c|c|}
\hline $\begin{array}{l}\text { Dep. Variable: } \\
r d_{t}\end{array}$ & $\begin{array}{l}\text { U.K. firms: } \\
\text { First Difference } \\
\text { GMM }\end{array}$ & $\begin{array}{c}\text { U.K. firms: } \\
\text { Two-step systems } \\
\text { GMM }\end{array}$ & $\begin{array}{c}\text { Continental } \\
\text { European firms: } \\
\text { First Difference } \\
\text { GMM } \\
\end{array}$ & $\begin{array}{c}\text { Continental } \\
\text { European firms: } \\
\text { Two-step systems } \\
\text { GMM }\end{array}$ \\
\hline$r d_{t-1}$ & $\begin{array}{c}1.136 * * * \\
(0.202)\end{array}$ & $\begin{array}{c}1.147^{* * *} \\
(0.174)\end{array}$ & $\begin{array}{c}0.611^{* * *} \\
(0.157)\end{array}$ & $\begin{array}{c}0.708^{* * *} \\
(0.150)\end{array}$ \\
\hline$r d_{t-1}^{2}$ & $\begin{array}{c}-0.550 * * * \\
(0.110)\end{array}$ & $\begin{array}{c}-0.592 * * * \\
(0.106)\end{array}$ & $\begin{array}{r}-0.101 \\
(0.069)\end{array}$ & $\begin{array}{c}-0.157 * * \\
(0.073)\end{array}$ \\
\hline$Y_{t}$ & $\begin{array}{l}0.007 \\
(0.038)\end{array}$ & $\begin{array}{l}0.012 \\
(0.033)\end{array}$ & $\begin{array}{l}0.037 \\
(0.028)\end{array}$ & $\begin{array}{l}0.042 \\
(0.027)\end{array}$ \\
\hline$Y_{t-1}$ & $\begin{array}{r}-0.052 \\
(0.033)\end{array}$ & $\begin{array}{c}-0.069 * \\
(0.039)\end{array}$ & $\begin{array}{c}-0.048^{* *} \\
(0.023)\end{array}$ & $\begin{array}{c}-0.047 * * \\
(0.021)\end{array}$ \\
\hline $\mathbf{C F}_{t}$ & $\begin{array}{l}0.117 \\
(0.081)\end{array}$ & $\begin{array}{l}0.142 \\
(0.088)\end{array}$ & $\begin{array}{c}0.135^{* *} \\
(0.068)\end{array}$ & $\begin{array}{l}0.148^{* *} \\
(0.065)\end{array}$ \\
\hline $\mathrm{CF}_{t-1}$ & $\begin{array}{l}0.024 \\
(0.094)\end{array}$ & $\begin{array}{l}0.066 \\
(0.091)\end{array}$ & $\begin{array}{r}-0.004 \\
(0.037)\end{array}$ & $\begin{array}{r}-0.050 \\
(0.037)\end{array}$ \\
\hline$s t k_{t}$ & $\begin{array}{c}0.173 * * * \\
(0.056)\end{array}$ & $\begin{array}{c}0.192^{* * *} \\
(0.044)\end{array}$ & $\begin{array}{r}-0.011 \\
(0.053)\end{array}$ & $\begin{array}{r}-0.022 \\
(0.077)\end{array}$ \\
\hline$s t k_{t-1}$ & $\begin{array}{c}-0.065^{* * *} \\
(0.022)\end{array}$ & $\begin{array}{c}-0.046 * * * \\
(0.017)\end{array}$ & $\begin{array}{l}0.023 \\
(0.032)\end{array}$ & $\begin{array}{l}0.011 \\
(0.035)\end{array}$ \\
\hline Observations & 352 & 352 & 825 & 825 \\
\hline Instruments & 87 & 87 & 87 & 87 \\
\hline CF Chi2 (p-value) & 0.107 & 0.007 & 0.038 & 0.137 \\
\hline Stk Chi2 (p-value) & 0.075 & 0.001 & 0.775 & 0.837 \\
\hline$A R(1)$ & 0.000 & 0.051 & 0.003 & 0.002 \\
\hline $\operatorname{AR}(2)$ & 0.782 & 0.755 & 0.886 & 0.846 \\
\hline Hansen & 0.782 & 0.635 & 0.278 & 0.186 \\
\hline Sargan & 0.000 & 0.000 & 0.094 & 0.191 \\
\hline
\end{tabular}

Note: All regressions are performed including time dummies.

Heteroskedasticity robust standard errors in parenthesis. ***, **, * indicate significance at 1,5 , and 10 percent respectively.

One step first difference GMM estimates in columns 1 and 3, and two-step Windmeijer corrected systems GMM estimates in columns 2 and 4 .

Instruments differenced equation are lagged levels dated t-3 to t-4 and instruments level equation are lagged differences dated $\mathrm{t}-2$.

The Chi2 tests are tests of the null that the sum of current and lagged cash flow and net stock issuance respectively is zero.

The AR-tests are asymptotically normally distributed under the null hypothesis of no serial autocorrelation.

The Hansen and Sargan tests are chi-square distributed under the null of exogenous instruments. 